\title{
Know-how and Know-why Nutrients may be Less Bioaccessible and Less Bioavailable due to Proton Pump Inhibitor - Food Interactions and Incompatibilities Involving Metal-Aquo Complexes
}

Helena Jenzer*, Irene Marty, Sandra Büsser, Marta Silva, Franziska Scheidegger-Balmer, Linda Jennifer Ruch, Sofia Martins, Noëmi Dajanah Maurer-Brunner, Francesca Rotunno and Leila Sadeghi

Bern University of Applied Sciences BFH, Health Division, R\&D Nutrition and Dietetics, Bern, Switzerland

\begin{abstract}
Background: Proton pump inhibitors change gastric $\mathrm{pH}$ from around 2.0 to 2.5 to more than 4.0 for up to 16 hours per day and suppress gastric function widely. Risk factors assigned to long-term inhibition of gastric acidity arise from cleavage-resistance of peptides and glycosides, mucosal degeneration and leak, loss of bactericidal action, and modification of absorption kinetics of medicines and nutrients.
\end{abstract}

This article aims to contribute to wisely use of proton pump inhibitors and to recommend nutritional options.

Methods: A systematic online literature research was performed on usual platforms. Recommendations rely on a multidisciplinary focus group assessment. Explanations arising from the retrieved references were tested for consistency by titration of iron solution from acidic to basic $\mathrm{pH}$ while observing precipitation.

Results and discussion: Literature describes bacterial overgrowth, community and hospital-acquired pneumonia, childhood asthma related to PPI treatments of mothers in pregnancy, sensitization to food allergens in the elderly and in pregnant women (as progesterone slows down gastric emptying), deterioration of intolerances, and various diseases such as celiac and inflammatory diseases. In addition to pathologies, bioavailability of medicines may be modified dramatically. For micronutrients, aquo-complexes of metal ions revealed to be a neglected issue in research of food-drug interactions arising from PPI treatments.

To prevent these complications, a focus group from a clinical support team recommends intermittent and ondemand strategies, alternative antacids, avoidance of high allergenic food, buffering, pepsin replacement, stimulation of digestion and peristalsis, and physical activity, and medicines review and reconciliation.

Conclusion: Proton pump inhibitor safety profiles are troubled by risk factors arising from inappropriate longterm use. Drugs' bioavailability may increase as a result of mucosal hyperpermeability, or decrease as a result of altered dissociation. Care should be given to substrates with $\mathrm{pK}_{\mathrm{a}}<4.5$ as well as to micronutrient supply. At least children and pregnant women should prefer alternative antacids.

Keywords: Bioavailability; Metal-aquo complex; Gastric acidity; Hypochlorhydria; Food-drug interactions; Medicines; Nutrients; Proton pump inhibitors; PPI adverse effects; PPI safety

\section{Introduction}

Gastric acid secretion is stimulated by meals, mainly by protein, calcium (both major fractions of milk), and carbohydrates. Pepsin activation and enzymatic protein digestion depend on a $\mathrm{pH}<3.0$ to 3.5. Mean gastric fasting $\mathrm{pH}$ is 2.15 for men and 2.8 for women [1]. As a result of its logarithmic scale, this apparently small $\mathrm{pH}$ difference corresponds to a nearly 5 -fold excess of gastric protons in males. Higher proton release in men seems to be justified by the physiological need to support muscle mass. The use of proton pump inhibitors (PPIs) to treat disorders such as gastroesophageal reflux disease (GERD), bleeding peptic ulcers, or severe reflux disease, changes gastric $\mathrm{pH}$ permanently to $>4.0$ [2]. In pharmacotherapy, to prevent peptic ulcers arising from non-steroidal anti-inflammatory drugs, it is widely accepted to combine them with PPIs. This combination treatment may last over several months or years in the case of arthrosis and degenerative rheumatic diseases.

Peptide bonds of proteins and acetal bonds of carbohydrates are both hydrolyzed enzymatically and non-enzymatically in an acidic environment. A major problem of raising gastric $\mathrm{pH}$ permanently is impaired non-enzymatic as well as acid catalyzed cleavage of peptide and glycosidic bonds, i.e. malfunction of proteolysis and hydrolysis of di-, oligo-, and polysaccharides. In the modified gastric environment, drugs and nutritional components may be differently soluble, differently dissociated, and/or differently hydrolyzed, and therefore have modified absorption and bioavailability profiles. The topic is of major public health importance due to high prevalence of gastrointestinal pathologies and number of PPI prescriptions worldwide, estimated to some 120 million annually $[3,4]$.

Multiple factors have an impact on bioavailability of drugs, i.e. [5]

- The drug's profile related to solubility and dissolution, i.e.

○ Dissociation degree

○ Hydrogen bond building

*Corresponding author: Prof. Dr. Helena Jenzer, Bern University of Applied Sciences, Health Division, R\&D Nutrition and Dietetics, Murtenstrasse 103008 Bern, Switzerland, Tel: +4131 84845 57; E-mail: helena.jenzer@bfh.ch

Received May 03, 2016; Accepted June 15, 2016; Published June 23, 2016

Citation: Jenzer H, Marty I, Büsser S, Silva M, Scheidegger-Balmer F, et al. (2016) Know-how and Know-why Nutrients may be Less Bioaccessible and Less Bioavailable due to Proton Pump Inhibitor - Food Interactions and Incompatibilities Involving MetalAquo Complexes. J Nutr Disorders Ther 6: 191. doi:10.4172/2161- 0509.1000191

Copyright: ( $\odot 2016$ Jenzer H, et al. This is an open-access article distributed under the terms of the Creative Commons Attribution License, which permits unrestricted use, distribution, and reproduction in any medium, provided the original author and source are credited. 
Citation: Jenzer H, Marty I, Büsser S, Silva M, Scheidegger-Balmer F, et al. (2016) Know-how and Know-why Nutrients may be Less Bioaccessible and Less Bioavailable due to Proton Pump Inhibitor - Food Interactions and Incompatibilities Involving Metal-Aquo Complexes. J Nutr Disorders Ther 6: 191. doi:10.4172/2161- 0509.1000191

Page 2 of 9

- Polar van der Waals surface area

○ Molecular weight, size, shape

○ Polar functions (hydrophilic - lipophilic balance)

○ Molecular flexibility

- The drug's permeability relying on physiological factors, i.e.

○ Preferred absorption site

- Mechanisms of membrane crossing

- By passive transport according to Fick's law

- By active mono- and/or bidirectional (efflux) transporters

- Lipid / bile acid transporters

- Monocarboxylate (organic anion) transporters

- Organic cation transporter

- Nucleoside transporters

- Intestinal dipeptide transporters

- Amino acid transporters

- Vitamin transporters

- Phosphate transporters

- P-glycoprotein transporters

- Food effects with fat content

- Surfactants

- Gastric emptying

- Transmucosal fluid flow (known as "solvent drag")

- Metabolism by CYP450 isoenzymes (mainly CYP3A4,5,7)

$\mathrm{pH}$ used to be measured either by potentiometry or by titration in older methods and reflect a value at a specific moment [6-8]. Results are differently integrated by the authors to the percentage of time intragastric $\mathrm{pH}$ is below 4 . Thus, these studies are of limited comparability. A more recent and refined approach to measure gastric acidity proposes to use an acidity index. This index weighs true molecular amounts of protons rather than $\mathrm{pH}[9]$.

The consequences of decreased long-term safety of PPIs and the stop of gastric functioning on nutrition are still understudied and conversely discussed.

The aim of this work is to assess the impact of permanent gastric acidity modification on the bioavailability of nutrients and medicines, and to propose alternative pharmaco-therapeutic and nutritional treatment options.

\section{Materials and Methods}

A systematic literature research was performed on Cochrane Library@, Medline ${ }^{\star}$, Google Scholar ${ }^{\circ}$, CC Med $^{\circledR}$, Medpilot ${ }^{\circ}$, and DIMDI*. Keywords were PPI, drug-induced hypochlorhydria, digestibility, safety, pregnancy, allergy, in vivo, human, acidity, replacement, and/or nutrient. More specific biochemical mechanisms were researched in a further manually performed ad hoc search. Further data was retrieved from product monographies dedicated for hospital pharmacy medicines information services.
Explanations arising from the references' interpretation were tested by titration of iron solution from acidic to basic $\mathrm{pH}$ conditions while observing precipitate formation. These simple tests were performed to confirm precipitation formation beginning around $\mathrm{pH}=\mathrm{pK}_{\mathrm{a}}$.

Therapeutic options are relying on a focus group approach integrating an interdisciplinary team of physicians, hospital pharmacists, and nutritionists.

\section{Results and Discussion}

Some risk factors of PPI-induced long-term inhibition of gastric acidity are of particular importance for nutritional assessment or nutrition support, i.e. [4]

- Loss of bactericidal effect

○ Bacterial overgrowth

- Mucosal degeneration

- Transmucosal leak

○ Hyperpermeability

- Modified absorption kinetics

- Reduction or increase of bioavailability of nutrients such as vitamins and oligoelements

- Reduction or increase of bioavailability of medicines

\section{Ad loss of bactericidal effect}

Peptic digestion is incomplete in the first two years of life. The antiseptic effect of acidity in the stomach develops within a few hours after birth. In full-term babies, the gastric acidity changes within one hour from 6.1 to 5.4, within 2 hours to 3.1 and within six hours to 2.2. $\mathrm{pH}$ increases afterwards for 10 days and decreases again slowly and slightly. Acid output similar to adults is reached by 24 weeks. Full adult values are not reached before an age of approximately 2 years [10]. Preterm born babies have a gastric $\mathrm{pH}>4$ for $80-90 \%$ of time, the acidity rising slowly with age [11].

As bactericidal effect decreases with raising $\mathrm{pH}$, the risk for bacterial, viral, and prion-associated infections increases. An increase in gastric $\mathrm{pH}$ to around 4.0 is observed for infants aged 1 to 12 months with chronic diarrhea and protein malnutrition, combined with bacterial overgrowth, which contains essentially Gram-negative bacilli in $57 \%$ of the cases. This bacterial overgrowth happens at the moment of the evolution of the disease to a chronic state. Breast-fed babies do not have bacterial overgrowth of gram-negative bacilli and no diarrhea, although they have a similar gastric $\mathrm{pH}$ to bottle-fed babies. This may be related to the transfer of protective factors e.g. immunoglobulines from lactating mothers. Therefore, an adequate gastric $\mathrm{pH}$ is determinant for complication-free adaption, mainly if babies are not breast-fed [12].

Children of 4 to 36 months suffering from GERD and treated with $\mathrm{H}_{2}$ antagonists or PPIs for 8 weeks showed a higher risk for acute gastroenteritis and community and/or hospital acquired pneumonia, although otherwise healthy. These risks sustain on stopping the therapy [13]. Alteration of gastric acid secretion may also bring with it chronic Helicobacter pylori infections. As acidity is also reduced in the upper aerodigestive tract, pneumonia is arising from increased bacterial larynx and esophagus colonization. In addition, Clostridium difficile - associated diarrhea is a complication of PPI treatment in adults and in children increasing in combination with statins. On behalf of microbiology, an acidic gastric $\mathrm{pH}$ of $<3$ is determinant for 
Citation: Jenzer H, Marty I, Büsser S, Silva M, Scheidegger-Balmer F, et al. (2016) Know-how and Know-why Nutrients may be Less Bioaccessible and Less Bioavailable due to Proton Pump Inhibitor - Food Interactions and Incompatibilities Involving Metal-Aquo Complexes. J Nutr Disorders Ther 6: 191. doi:10.4172/2161- 0509.1000191

Page 3 of 9

bactericidal activity and thus protection against bacterial overgrowth of Clostridium difficile, Capylobacter jejuni, and Salmonella ssp [13]. This is also true for the inflammation, ulcer, and stomach cancer associated Helicobacter pylori which produces big amount of urease leading to a shift in gastric $\mathrm{pH}$ from between 2.2-2.8 to a range of 6-7 [14].

\section{Ad mucosal degeneration}

Alterations of gastric $\mathrm{pH}$ increases the risk for polyps, enterochromaffin-like (ECL) cell hyperplasia, carcinoid, gastrinoma, and cancer, in combination with transmucosal leak and hyperpermeability proximal to duodenum, occurring within a few days after PPI therapy start and being reversible within a few days of discontinuation. Undigested persisting proteins, peptides, allergenes and drugs may be absorbed more readily. Digestion-resistance and persistence of food protein during gastric transit are documented risk factors for sensitization to food allergens for elderly patients around 65 years or pregnant women, who suffer also from slower gastric emptying due to progesterone. Concomitant PPI use and degradation of various pathologies such as lactose intolerance, celiac disease, atrophic gastritis, rheumatoid arthritis, and/or diabetes mellitus, are reported being correlated positively. Some are gender-different as well as a result of estradiol-receptor-dependent mast-cell activation [15-19]. Community and hospital-acquired pneumonia show an increased risk ratio of 1.89 in PPI patients. An increase of asthma among children is also associated with PPI treatments of their mothers in pregnancy. The association is evident as a result of increasing food-specific IgE antibodies within 3 months and is postulated to arise from increased type 2 helper cell bias in the offspring, thus from predisposition to increased atrophy [20].

\section{Ad modified absorption kinetics}

In addition to allergens, higher and potentially dangerous amounts of drugs may be available in the course of long-term PPI treatment as a result of drug-drug and food-drug interactions. On the other hand, a decreased bioavailability due to long-term PPI pharmacotherapy is described for vitamins' and for oligoelements' absorption, e.g. of ascorbic acid ( $\mathrm{pK}$ 4.19), cyanocobalamin, zinc, iron, magnesium, folate, and calcium depending on their salt and thus $\mathrm{pH}$-dependent solubility [21-25]. Calcium depletion is likely to induce osteoporosis, while the risk of hypomagnesemia due to long-term PPI treatment has been subject of an FDA notification to healthcare professionals and the public in March 2011 [26]. Some of these deficiencies are reported to be not significant while short-term treatments. However, such studies include in general very few patients.

Modification of absorption kinetics is described for many drugs such as ketoconazole, itraconazole, atazanvir, cefpodoxime, cinnarizine, enoxacin, or dipyridamole, which are less bioavailable as a result of altered dissociation, and of nifedipine, digoxin, penicillins, erythromycin, or alendronate, which are more bioavailable as a result of mucosal hyperpermeability [27]. The reason for altered absorption kinetics of medicines can be explained by the change of both solubility and charge. As a result of gradually increasing $\mathrm{pH}$ in the gastrointestinal tube and depending on their acid dissociation constant $\mathrm{pK}$, drugs and nutritional components are differently soluble and differently available for absorption in various parts of the tube. Uncharged solubilized molecules will be readily absorbed by passive diffusion. At $\mathrm{pK}_{\mathrm{a}}=\mathrm{pH}, 50 \%$ of a molecule is dissociated and $50 \%$ undissociated. In a dissociated and charged form, a molecule is worse passively absorbed in the GI tube. Thus, all weak acids bases with $\mathrm{pK}_{\mathrm{a}}<4$ can give rise to undesirable effects, if gastric $\mathrm{pH}$ will no longer remain in a physiological range but rather be over 4 . In this milieu, the fraction of the readily absorbable undissociated amount decreases and the deprotonated form will markedly increase. Generally speaking, weak acids retain a lower fraction of their undissociated state if $\mathrm{pH}$ raises and are therefore less bioavailable as a result of lower passive diffusion. Functional groups with an acid dissociation constant $\mathrm{pK}_{\mathrm{a}}<4$ such as carboxylic acids, vinylogous carboxylic acids, acid halides, -I-mono- or disubstituted phenols, or sulfonic acids are those who can lead to a loss of bioavailable medicine under PPI treatment, e.g. many non-steroidal anti-inflammatory drugs and ascorbic acid. On the other hand, weak bases will have a higher fraction of undissociated state if $\mathrm{pH}$ raises and are therefore more bioavailable as a result of higher diffusion (Table 1 and Figure 1).

For oligoelements, apart from dietary factors, another reason for malabsorption must be found [28]. At first sight, their charge does not seem to depend on $\mathrm{pH}$. However, both acidic $\mathrm{pH}$ and ascorbic acid (in fruit juice) stabilize iron in its ferrous state by ascorbate chelation. Rapid re-oxidation occurs at neutral $\mathrm{pH}$. $\mathrm{Fe}(+\mathrm{III})$ has a high charge density, a small ionic radius $(0.067 \mathrm{~nm})$ and easily excited outer electrons, thus prefers oxygen ligands, e.g. phenolate, carboxylate, whereas $\mathrm{Fe}(+\mathrm{II})$ has a lower charge density, a larger ionic radius $(0.083$ $\mathrm{nm}$ ) and less easily excited outer electrons, thus prefers nitrogen and sulfur ligands, e.g. imidazole, pyrrole, thiolate, or methionine. Metal salts dissolved in water are hydrolyzed. Oligoelement cations exist as aquo-complexes and are therefore weak acids. Polarization of the coordinated water molecules depends on the oxidation state and the size of the cation. Ferric aquo-complexes are more acidic than the ferrous. Deprotonation of coordinated water from ferric aquocomplexes occurs immediately at $\mathrm{pH}$ going towards basic, whereas ferrous aquo-complexes remains longer undissociated due to the absence of oxygen and other oxidizing agents. Iron will exist at acidic conditions in the stomach as hexaaquairon(III) ion, $\left[\mathrm{Fe}\left(\mathrm{H}_{2} \mathrm{O}\right)_{6}\right]^{3+}$. As $\mathrm{pH}$ raises, this aquo-complex is deprotonated to $\left[\mathrm{Fe}\left(\mathrm{H}_{2} \mathrm{O}\right)_{5}(\mathrm{OH})\right]^{2+}$ as a result of $\mathrm{pK}_{\mathrm{a}}=2.2$, to $\left[\mathrm{Fe}\left(\mathrm{H}_{2} \mathrm{O}\right)_{4}(\mathrm{OH})_{2}\right]^{+}$as a result of $\mathrm{pK}=3.5$, and to $\left[\mathrm{Fe}\left(\mathrm{H}_{2} \mathrm{O}\right)_{3}(\mathrm{OH})_{3}\right]^{0}$ as a result of $\mathrm{pK}_{\mathrm{a}}=6.0$. Thus, already at weakly acidic $\mathrm{pH}$ and increasingly above approximately $\mathrm{pH} 5$, significant amounts of secondary colloidal iron (III) hydroxides and an amorphous redbrown ferric hydroxide precipitate are formed. After elimination of water from the aquohydroxo complexes, ferric iron will condensate by formation of hydroxo bridges. These mechanisms occurring at natural $\mathrm{pH}$ make ferric iron more and more insoluble and unsuitable for absorption.

$\left[\mathrm{Fe}\left(\mathrm{H}_{2} \mathrm{O}\right)_{6}\right]^{3+}$ in its deprotonated form is reduced in the distal duodenum to $\left[\mathrm{Fe}\left(\mathrm{H}_{2} \mathrm{O}\right)_{6}\right]^{2+}$ at $\mathrm{pH}$ between 5 and 6 at the duodenojejunal junction. A first $\mathrm{pK}$ of the ferrous iron aquo-complex is situated at 6.74 and a second at 9.5. Ferrous condensates form only above $\mathrm{pH} 6$ [29-31]. It is well known that iron is mainly actively absorbed as ferrous iron $\mathrm{Fe}\left(\mathrm{II}^{+}\right)$in the upper duodenal part of the GI tube where the luminal $\mathrm{pH}$ gradient raises steeply in the proximal $10 \mathrm{~cm}$ of the duodenum. Acidity passes at this site from $\mathrm{pH} 2$ to $\mathrm{pH} 5$ in the fasting state and from $\mathrm{pH} 1.7$ to $\mathrm{pH} 4.3$ in the second and third postprandial hour [32]. Iron absorption is known to be enhanced almost 3 fold by ascorbic acid or orange juice. The juice's acidity is able to override the lack of the diminished acidity produced by the proton pump. On the other hand, the absorption is competed by binding to tannins and components of many beverages derived from tea or coffee. As a result, ferric iron tends to be lost on current PPI treatment and loss of acidity, mainly due to formation of iron (III) hydroxides as colloids or precipitates, therefor lost for reduction to the ferrous state and absorption. 
Citation: Jenzer H, Marty I, Büsser S, Silva M, Scheidegger-Balmer F, et al. (2016) Know-how and Know-why Nutrients may be Less Bioaccessible and Less Bioavailable due to Proton Pump Inhibitor - Food Interactions and Incompatibilities Involving Metal-Aquo Complexes. J Nutr Disorders Ther 6: 191. doi:10.4172/2161- 0509.1000191

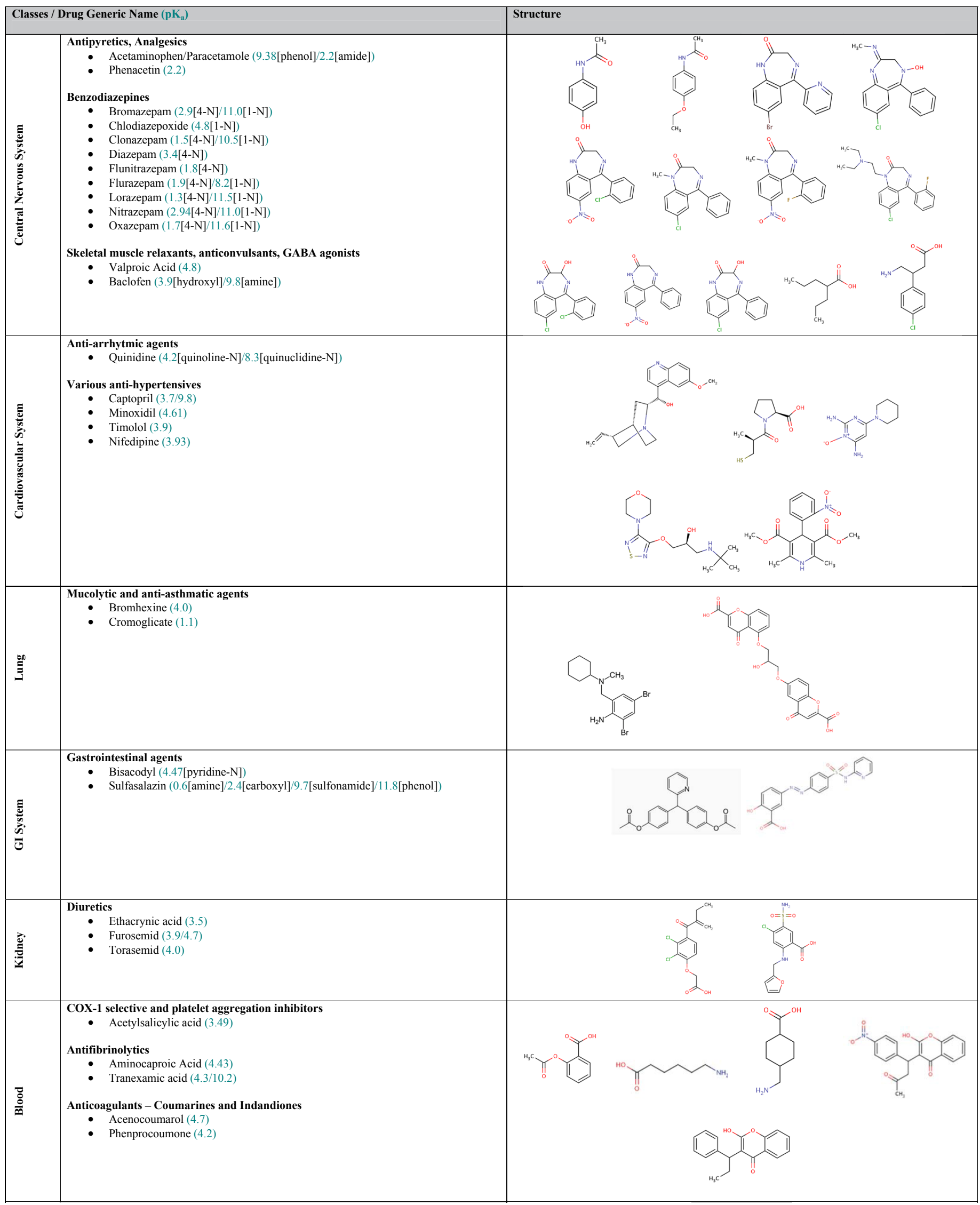


Citation: Jenzer H, Marty I, Büsser S, Silva M, Scheidegger-Balmer F, et al. (2016) Know-how and Know-why Nutrients may be Less Bioaccessible and Less Bioavailable due to Proton Pump Inhibitor - Food Interactions and Incompatibilities Involving Metal-Aquo Complexes. J Nutr Disorders Ther 6: 191. doi:10.4172/2161- 0509.1000191

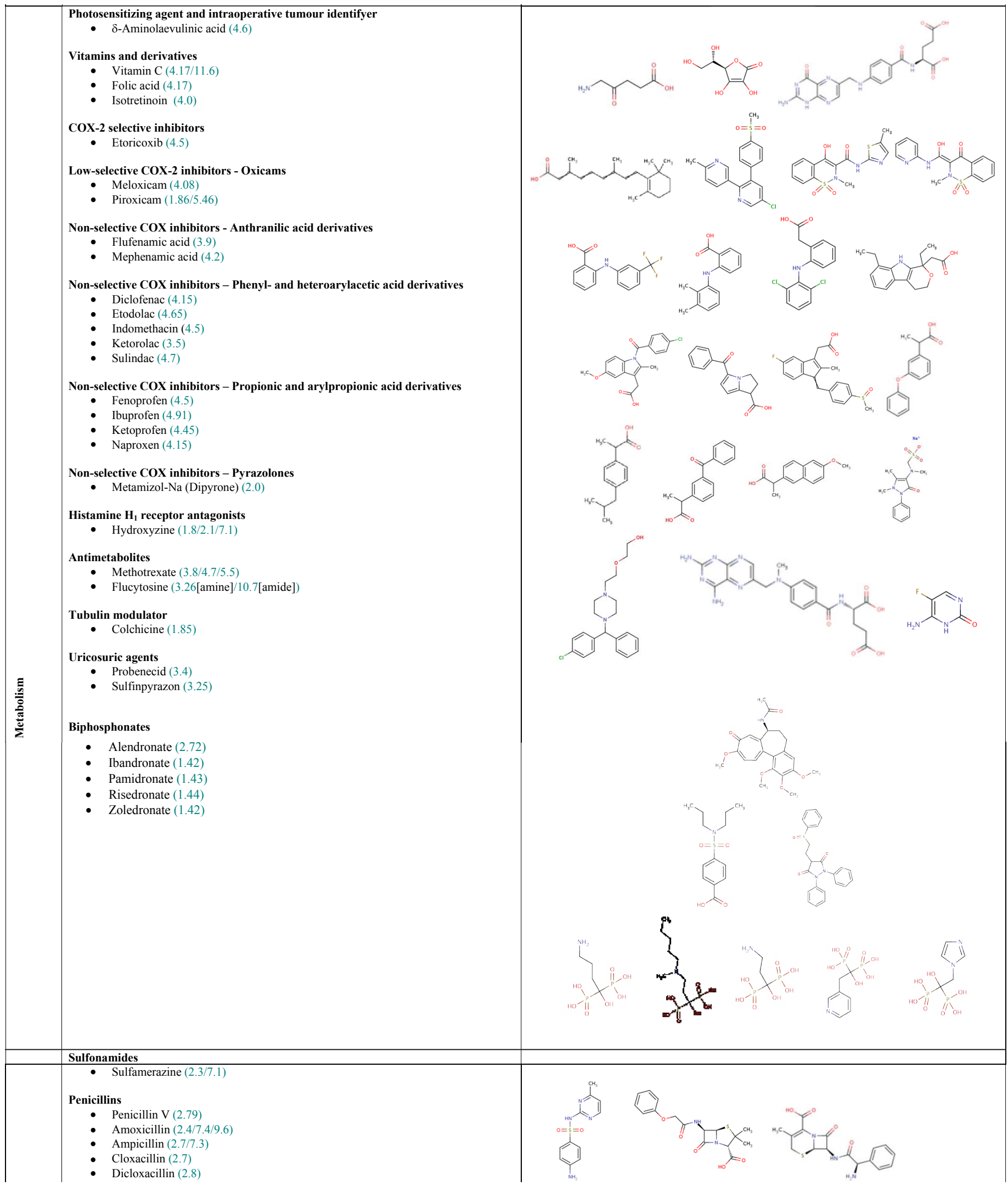


Citation: Jenzer H, Marty I, Büsser S, Silva M, Scheidegger-Balmer F, et al. (2016) Know-how and Know-why Nutrients may be Less Bioaccessible and Less Bioavailable due to Proton Pump Inhibitor - Food Interactions and Incompatibilities Involving Metal-Aquo Complexes. J Nutr Disorders Ther 6: 191. doi:10.4172/2161- 0509.1000191

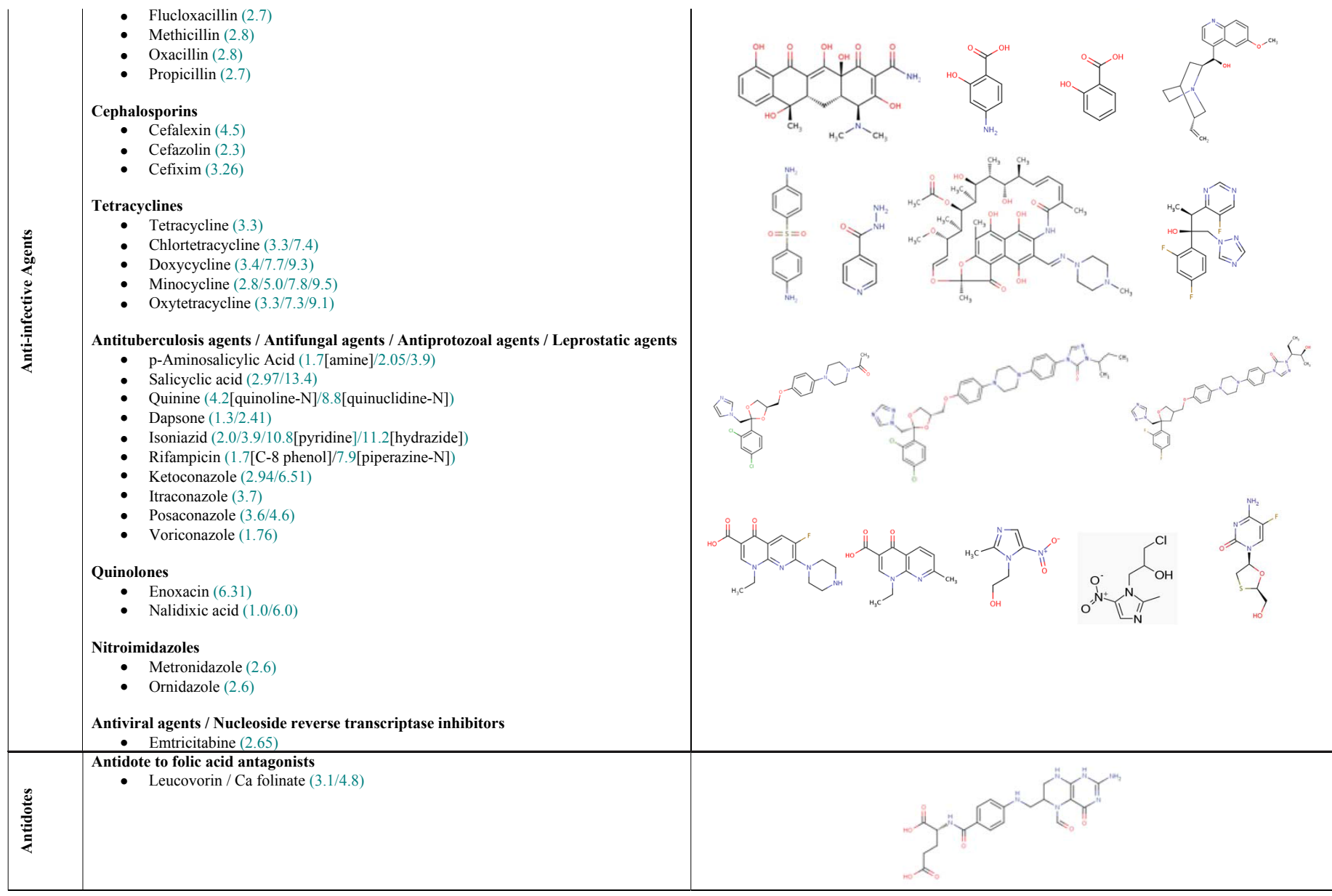

Table 1: Examples of weak acids and bases prone to a drop of bioavailability in the course of long-term PPI treatment (ascorbic acid, ketoconazole, itraconazole, atazanavir, cefpodoxime, cinnarizine, enoxacin, dipyridamole, ...). The solubility of weak acids are particularly concerned by altered pH conditions in the gastrointestinal tube. Missing acidity leads to deprotonation and decreased absorption of the charged molecules.

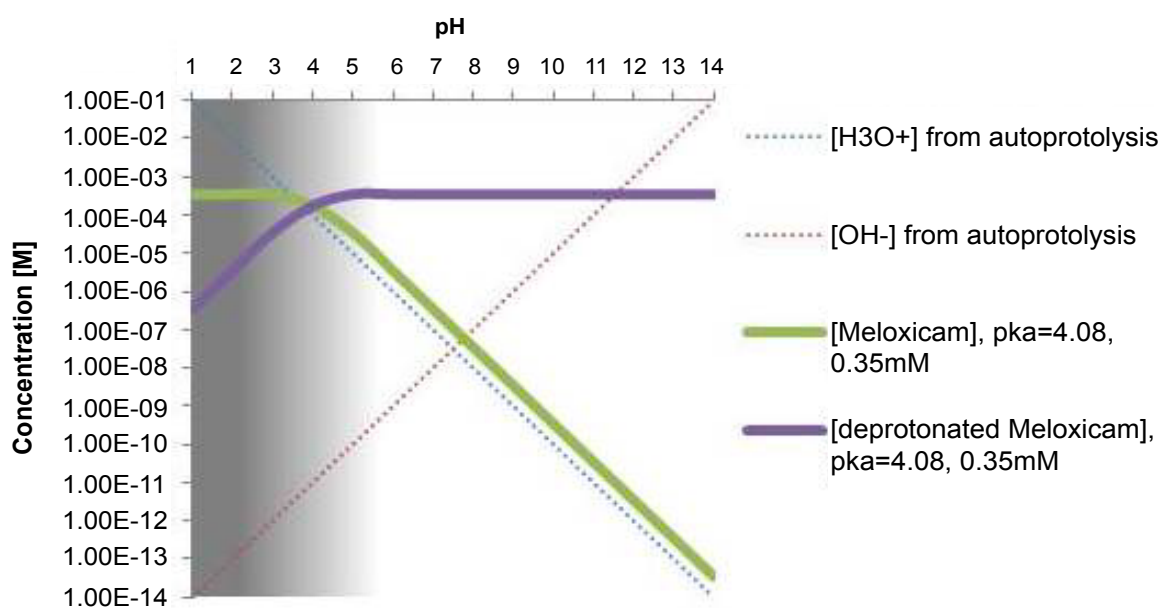

Log-conc-diagram of meloxicam (as a representative of weak acids) and its deprotonated form $\left(\mathrm{M}_{\mathrm{r}} 351.4\right.$, pK $\left.\mathrm{a}_{\mathrm{a}} 4.08\right)$, and of protons and hydroxides from auto-protolysis of water, as a function of $\mathrm{pH}$. The log-conc diagram demonstrates the change of the ratio between undissociated and dissociated molecules. The concentration of meloxicam / deprotonated meloxicam is $\mathrm{c}=0.35 \mathrm{mM}$ corresponding to a dose of $15 \mathrm{mg}$ in $125 \mathrm{ml}$ gastric juice (mean value of fluid volume for both genders). The graph is also applicable for a weak base and its protonated form instead of the vinylogous carboxylic acid meloxicam. In case of PPI treatment, acidic gastric pH of less than about 4 is no longer achieved. As a result, acids and bases with $\mathrm{pK}_{\mathrm{a}} \leq 4.5$ (shadowed range) are differently dissociated, thus differently soluble and therefore may be differently bioavailable than presumed. Passing from an acidic $\mathrm{pH}$ towards a basic $\mathrm{pH}$ decreases the absorbable undissociated form and increases the charged dissociated form which is likely to be absorbed worse.

Figure 1: log-conc-diagram. 
Citation: Jenzer H, Marty I, Büsser S, Silva M, Scheidegger-Balmer F, et al. (2016) Know-how and Know-why Nutrients may be Less Bioaccessible and Less Bioavailable due to Proton Pump Inhibitor - Food Interactions and Incompatibilities Involving Metal-Aquo Complexes. J Nutr Disorders Ther 6: 191. doi:10.4172/2161- 0509.1000191

Page 7 of 9

Similar contemplations are applicable for copper, cobalt, zinc, manganese and further elements with important co-factor functions in metabolism. Transportation across the membrane can be further antagonised competitively by other metal ions such as manganese, cobalt, nickel, chrom, or zinc which use the same symporters. pK values for copper $\left(\mathrm{II}^{+}\right)$hexaquo-complexes are 6.8 and 8.5 , for cobalt $\left(\mathrm{II}^{+}\right)$hexaquo-complexes 8.8 and 12.4 , manganese $\left(\mathrm{II}^{+}\right)$hexaquocomplexes 10.7 and 12.0, and for zinc hexaquo-complexes 8.96 and $10.1[33,34]$.

\section{Discussion of coping strategies for prevention and intervention}

Proton pump inhibitors are beneficial for many patients as well as a risk factor for others. Their prescription and use must be carefully assessed. A risk-benefit ratio must be evaluated on a personalized nutrition and medicine basis.

- Alternative antacids, step-down, intermittent and ondemand strategies

- $\mathrm{MgCO}_{3}$ and $\mathrm{H}_{2}$-antagonists have a shorter onset and time of $\mathrm{pH}>3-4$ than pantoprazole $40 \mathrm{mg}$ (median $\mathrm{pH}=3.7$, $\mathrm{pH}>4$ for $10.8 \mathrm{~h}$ ) or esomeprazole $40 \mathrm{mg}$ (median $\mathrm{pH}=4.7$, $\mathrm{pH}>4$ for $16.1 \mathrm{~h}$ ).

\section{- To avoid high allergenic food}

i.e. Crustacean, eggs, fish, milk, peanuts, soybeans, tree nuts or fruits, and wheat

- Buffering, pepsin replacement, stimulation of digestion and peristalsis

- Carbonated beverages, quinine water, aperitifs, appetizers, and bitter substances (amara)

o Prokinetic agents (domperidone, bromopride, metoclopramide, quinine, erythromycin)

- Mucosal protectors (curcumin, quercetin, alginates, pectins, glycyrrhizin)

○ Melatonin (regulates digestion and has structural similarity to omeprazole)

- Pepsin in $\mathrm{HCl}$ preparations

- Nutrition and dietary approach combined with physical activity
○ High-dietary fiber
○ Low-fat diet
○ Low-carb diet, i.e. $<20 \mathrm{~g} / \mathrm{d}$

\section{- Reassessment of pharmacotherapy}

○ Weak acids $\left(\mathrm{pK}_{\mathrm{a}}<4.5\right)$ lose their undissociated state required for diffusion across membranes.

○ Absorption is impaired by membrane-bound CYP3A4,5,7 and efflux transporter P-gp.

Use of antacids (alternatives, step-down, intermittent and ondemand strategies)

Carbonates available over the counter, e.g. in a dose of $1360 \mathrm{mg}$ as calcium-magnesium-salt, will have an onset of about 6 minutes and a time with pH values over 3.0 of about $2 \frac{1}{2}$ hours. For an $\mathrm{H}_{2}$-antagonist, e.g. ranitidine $75 \mathrm{mg}$, the onset is 65 minutes and the time of $\mathrm{pH}>3.0$ is 13 hours and 36 minutes [35]. For pantoprazole $40 \mathrm{mg}$ and esomeprazole $40 \mathrm{mg}$, the most widely used PPIs, the median $24 \mathrm{~h} \mathrm{pH}$ are 3.7 versus 4.7 respectively after 5 days of treatment and the times of $\mathrm{pH}>4$ are 16.1 hours (esomeprazol) and 10.8 hours (pantoprazol) respectively. The values have been measured after oral administration to volunteers of Western European countries and New Zealand. Acid production by the proton pump can only be restored through biosynthesis of the $\mathrm{H}^{+} \mathrm{K}^{+}$-exchanging ATPase. The production half-life is approximately 50 hours. On PPI stop, a strong rebound hypersecretion is reported, increasing secretory capacity compared to the one existing before the introduction of PPI [2,36-39]. It may be wise to restrictively prescribe antacids which shift $\mathrm{pH}$ to $>3-4$ permanently, mainly in the treatment of pregnant women and children.

\section{Beware of high allergenic food groups}

Under PPI treatment special attention has to be paid to the eight food groups which account for $90 \%$ of food-allergic reactions, i.e. crustacean, eggs, fish, milk, peanuts, soybeans, tree nuts or fruits, and wheat.

\section{Buffering and substituting gastric juice, stimulation of peristalsis, alternative GERD therapies}

After a complete nutrient drink, gastric $\mathrm{pH}$ and buffer capacity increase from between 7 and $18 \mathrm{mmol} \mathrm{L}^{-1} \Delta \mathrm{pH}^{-1}$ to between 14 and 28 mmol L ${ }^{-1} \Delta \mathrm{pH}^{-1}$. Gastric pepsin levels are doubled. Duodenal values are initially pre- and post-prandial similar, but duodenal $\mathrm{pH}$ decreases slowly to 5.2 , and buffer capacity increases from between $5.6 \mathrm{mmol} \mathrm{L}^{-1}$ $\Delta \mathrm{pH}^{-1}$ to between 18 and $30 \mathrm{mmol} \mathrm{L}^{-1} \Delta \mathrm{pH}^{-1}$. Bile salt levels are two to four times higher postprandial. In case of hypoacidity, it may be wise to precondition gastrointestinal $\mathrm{pH}$ preprandial by carbonated beverages or a buffering aperitif and/or appetizers. However, protein, carbohydrates, and calcium should be restricted due to their intense stimulation of gastric acidity and secretion. Supply of strong acidic drinks are not recommended due to high sensitivity of patients to acids. Peristalsis may be stimulated by drugs, e.g. domperidone, bromopride, metoclopramide, quinine, or erythromycin (beware of adverse drug reactions), or by bitter substances and amara which are in general terpenoids extracted from officinal plant preparations, e.g. Absinthii herba, aurantii immaturi pericarpium, Cardui benedicti herba, Centaures herba, Citri rec. pericarpium, Condurango cortex, Gentiana radix, Lichen islandicus, Quassiae lignum. These plants may be even more promising in combination with flavonoids due to antiinflammatory and anti-ulcer effects.

Due to its analogy to a partial structure of omeprazole, melatonin, orally given or induced by light exposure, is reported to an alternative to PPI treatment, providing control of the lower esophageal sphincter and neutralization of gastric acid secretion by induction of bicarbonate secretion in the duodenal epithelium. Curcumin and Quercetin have not been explored in human GERD trials, but in vitro and animal data suggest more potential than older medications with alginates, pectins, and glycyrrhizin analogs.

\section{Nutrition and dietary approach}

High-dietary fat is increasing GERD risk, while high-dietary fiber is decreasing GERD risk. It is unclear if high-dietary fat effects are independent of obesity. Low-carb diet, i.e. $<20 \mathrm{~g} / \mathrm{d}$, in obese individuals with GERD significantly reduces acid exposure. Carbonated beverages may be a treatment option on an individual basis, alone or combined 
Citation: Jenzer H, Marty I, Büsser S, Silva M, Scheidegger-Balmer F, et al. (2016) Know-how and Know-why Nutrients may be Less Bioaccessible and Less Bioavailable due to Proton Pump Inhibitor - Food Interactions and Incompatibilities Involving Metal-Aquo Complexes. J Nutr Disorders Ther 6: 191. doi:10.4172/2161- 0509.1000191

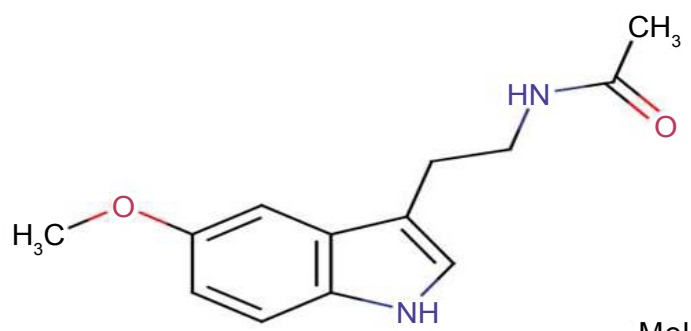

Melatonin

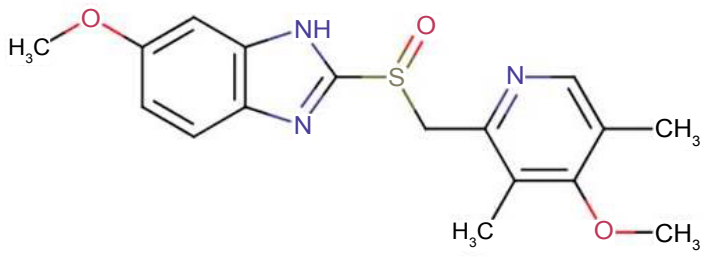

\section{Omeprazole}

Structure comparison melatonin - omeprazole. Melatonin has a slight similarity to PPIs which is however not sufficient for a structure-activity-relationship. Heterocycles as well as N-N distances are determinant for similar responses on the gastrointestinal tract mucosa as related to their protective effect. There is no pyridine-methylsubstituted sulfoxide and its indole- $\mathrm{N}$ is not protonable as are benzimidazoles. Thus, melatonin acts rather as an antioxidant than as inhibitor of the $\mathrm{H}+/ \mathrm{K}+-\mathrm{ATPase}-$ pump.

Figure 2: Structure comparison melatonin - omeprazole.

with modifying lifestyle and increasing physical activity.

To provide sufficient amounts of micronutrients, combination with ascorbic acid and, as far as supported, acidic beverages is likely to facilitate absorption [40].

\section{Replacement of pepsin}

If pepsin secretion is too low, classical pepsin / hydrochloric acid preparations can deliver 2 to $20 \mathrm{mmol}$ protons per single dose.

\section{Reassessment of pharmacotherapy}

Absorption upon oral intake is only possible if a substrate can migrate across double-layered membranes by either active carrier driven transport, ion pair or particulate absorption, facilitated or passive diffusion, or hydrophilic diffusion within pores filled with water. Most drugs pass membranes by diffusion. Only undissociated fractions are lipid soluble and can pass membranes by diffusion (Figure 2). Very polar drugs such as poly-alcohols are as a rule hardly bioavailable upon oral intake and may have a laxative effect instead. This is not the case for (primary) nutrients. Monosaccharides, aminoacids, as well as other physiological ingredients of a living cell, or closely related derivatives however, although highly polar as well, are absorbed due to carriers. These membrane passages, above all diffusions, are obviously qualitatively and quantitatively altered with modified acidic-alkaline condition. This situation is even complicated by membrane-bound enzymes such as CYP3A4,5,7 and the efflux transporter P-glycoprotein.

Extraction of substrates from the gastrointestinal tract into circulation is comparable to toxicological-pharmaceutical analytics techniques for extraction of undissociated analytes from a solution using the Stas-Otto separation-procedure [41]. The dissociation degree of a substance can be modified by changing $\mathrm{pH}$ conditions of the solution. At a $\mathrm{pH}$ corresponding to the $\mathrm{pK}_{\mathrm{a}}, 50 \%$ of a component is dissociated and $50 \%$ not. At a $\mathrm{pH}$ of +1 or -1 of the $\mathrm{pK}$ value, the ratio is $90 \%$ to $10 \%$, at $\mathrm{pH}$ of + or -2 this ratio is $99 \%$ to $1 \%$. This principle demands that the $\mathrm{pH}$ of the aqueous analyte is gradually varied from 1 to $4-5$ to $11-12$ and to $9-10$. On each extraction step, depending on the substances' $\mathrm{pK}$, not-dissociated molecules can be extracted using organic solvents. At the end, only very polar, e.g. charged, substances remain in the aqueous fraction.

As a result of gradually increasing $\mathrm{pH}$ in the gastrointestinal tube and depending on their acid dissociation constant $\mathrm{pK}_{\mathrm{a}}$, drugs and nutritional components are differently soluble and available for absorption in the corresponding part of the tube. Weak acids and weak bases are concerned as long as most of their undissociated form exists at $\mathrm{pH} \leq 4$. These molecules contain functional groups such as carboxylic acids, acid halides, phenols mono- or disubstituted by -I-groups, sulfonic acids. Weak acids will have a lower fraction of their undissociated state if $\mathrm{pH}$ raises and are therefore less bioavailable as a result of lower diffusion, whereas weak bases will have a higher fraction of undissociated state if $\mathrm{pH}$ raises and are therefore more bioavailable as a result of higher diffusion (Table 1 and Figure 1). The functional lack of the gastric absorption possibility at $\mathrm{pH}<4$ may be partly compensated in lower parts of the tube at $\mathrm{pH}>4$, if and where the substrate regains its undissociated absorbable form.

\section{Conclusion}

In spite of a good short-term safety profile and of the relief PPIs provide to affected patients, it is unanimously accepted that long-term PPI treatment and permanent acidic secretion inhibition brings along some risk factors, e.g. bacterial overgrowth, mucosal degeneration, hyper permeability, altered bioavailability as a result of modified absorption kinetics. Drugs may be more bioavailable as a result of mucosal hyper permeability, or less bioavailable as a result of the missing acid part of the gastrointestinal tube and therefore altered dissociation. Care should be given to substrates with $\mathrm{pK}_{\mathrm{a}}$ of about $\mathrm{pH}<4.5$. Micronutrients having a function as co-factors in metabolism may be partially lost as dissociation of their aquo-complexes change depending on $\mathrm{pH}$ conditions. Whereas the loss of oligoelements such as iron on current PPI treatment may become critic, the loss of NSAID has less consequences as these medicines are given at higher doses eventually still sufficiently above the minimal therapeutic threshold. 
Citation: Jenzer H, Marty I, Büsser S, Silva M, Scheidegger-Balmer F, et al. (2016) Know-how and Know-why Nutrients may be Less Bioaccessible and Less Bioavailable due to Proton Pump Inhibitor - Food Interactions and Incompatibilities Involving Metal-Aquo Complexes. J Nutr Disorders Ther 6: 191. doi:10.4172/2161- 0509.1000191

Inappropriate long-term PPI therapies should be avoided or replaced in some at risk cases by antacids with a shorter effect. Therapeutic options include alternative antacids, avoiding high allergenic food groups, buffering, stimulation of peristalsis, replacement of pepsin, and reassessment of drug therapy.

\section{Acknowledgement}

This work was supported by BFH grant J.003039-42-ERBQ.

\section{References}

1. Freire AC, Basit AW, Choudhary R, Piong CW, Merchant HA (2011) Does sex matter? The influence of gender on gastrointestinal physiology and drug delivery. Int J Pharm 415: 15-28.

2. Wilder-Smith $\mathrm{CH}$, Bondarov $\mathrm{P}$, Lundgren $\mathrm{M}$, Niazi M, Rohss K, et al. (2005) Intravenous esomeprazole (40 mg and $20 \mathrm{mg}$ ) inhibits gastric acid secretion as effectively as oral esomeprazole: results of two randomized clinical studies. European Journal of Gastroenterology \& Hepatology 17:191-197.

3. Statista (2013) The statistics portal. Top 10 proton pump inhibitors based on U.S. prescriptions in 2013.

4. Sandberg-Lewis S (2011) Proton pump inhibitors- a risky experiment?.

5. van de Waterbeemd H, Camenisch G, Folkers G, Chretien JR, Raevsky OA (1998) Estimation of blood-brain barrier crossing of drugs using molecular size and shape, and H-bonding descriptors. J Drug Target 6: 151-165.

6. Ebers DW, Gibbs GE, Smith DI (1956) Gastric acidity on the first day of life Pediatrics 18: 800-802.

7. Miller RA (1941) Observations on the gastric acidity during the first month of life. Arch Dis Child 16: 22-30.

8. Boyle JT (2003) Acid secretion from birth to adulthood. J Pediatr Gastroentero Nutr 37 Suppl 1: S12-16.

9. Tutuian R, Castell DO, Xue S, Katz PO (2004) The acidity index: a simple approach to the measurement of gastric acidity. Aliment Pharmacol Ther 19: $443-448$.

10. Deren JS (1971) Development of structure and function in the fetal and newborn stomach. Am J Clin Nutr 24: 144-159.

11. Sondheimer JM, Clark DA, Gervaise EP (1985) Continuous Gastric pH Measurement in Young and Older Healthy Preterm Infants Receiving Formula and Clear Liquid Feedings. J Pediatr Gastroenterol Nutri 4: 352-355.

12. Maffei HV, Nóbrega FJ (1975) Gastric pH and microflora of normal and diarrhoeic infants. Gut 16: 719-726.

13. Pali-Schöll I, Jensen-Jarolim E (2011) Anti-acid medication as a risk factor for food allergy. Allergy 66: 469-477.

14. Dunn BE, Campbell GP, Perez-Perez GI, Blaser MJ (1990) Purification and characterization of urease from Helicobacter pylori. J Biol Chem 265: $9464-$ 9469.

15. Untersmayr E, Jensen-Jarolim E (2008) The role of protein digestibility and antacids on food allergy outcomes. J Allergy Clin Immunol 121: 1301-1308.

16. Jensen-Jarolim E, Untersmayr E (2008) Gender-medicine aspects in allergology. Allergy 63: 610-615

17. Teramura-Groenblad M, Hosia-Randell H, Muurinen S, Pitkala K (2010) Use of proton-pump inhibitors and their associated risks among frail elderly nursing home residents. Scand J Prim Health Care 28: 154-159.

18. Tursi A (2004) The treatment of gastro-esophageal reflux disease in adult celiac disease. J Clin Gastroenterol 38: 724-726.

19. Mehta N, Saha S, Chien EKS, Esposti SD, Segal S, Esposti SD (2010) Disorders of the Gastrointestinal Tract in Pregnancy, de Swiet's Medical Disorders in Obstetric Practice: Wiley-Blackwell pp: 256-292.

20. Dehlink E, Yen E, Leichtner AM, Hait EJ, Fiebiger E (2009) First evidence of a possible association between gastric acid suppression during pregnancy and childhood asthma: a population-based register study. Clinical \& Experimental Allergy 39: 246-253.

21. Henry EB, Carswell A, Wirz A, Fyffe V, McColl KE (2005) Proton pump inhibitors reduce the bioavailability of dietary vitamin $\mathrm{C}$. Aliment Pharmacol Ther 22: 539-545.
22. Hutchinson C Geissler CA, Powell JJ, Bomford A (2007) Proton pump inhibitors suppress absorption of dietary non-haem iron in hereditary haemochromatosis. Gut 56: 1291-1295.

23. Ogawa R, Echizen H (2010) Drug-drug interaction profiles of proton pump inhibitors. Clin Pharmacokinet 49: 509-533.

24. Howden CW (2000) Vitamin B12 levels during prolonged treatment with proton pump inhibitors. J Clin Gastroenterol 30: 29-33.

25. Fournier MR, Targownik LE, Leslie WD (2009) Proton pump inhibitors osteoporosis, and osteoporosis-related fractures. Maturitas 64: 9-13.

26. Hoorn EJ, van der Hoek J, de Man RA, Kuipers EJ, Bolwerk C, et al. (2010) A case series of proton pump inhibitor-induced hypomagnesemia. Am J Kidney Dis 56: $112-116$

27. Lahner E, Annibale B, Fave GD (2009) Systematic review: impaired drug absorption related to the co-administration of antisecretory therapy. Alimentary Pharmacology \& Therapeutics 29: 1219-1229

28. Benito P, Miller D (1998) Iron absorption and bioavailability: An updated review. Nutrition Research 18: 581-603.

29. Buerge I (1999) Influence of $\mathrm{pH}$, Organic Ligands, and Mineral Surfaces on the Reduction of Chromium(VI) by Iron(II). A dissertation submitted to the Swiss Federal Institute of Technology Zn rich ETHZ for the degree of Doctor of Natural Sciences, Zul’rich.

30. Jolivet JP, Chanéac C, Tronc E (2004) Iron oxide chemistry. From molecular clusters to extended solid networks. Chem Commun (Camb) pp: 481-487.

31. Crichton R (2009) Solution chemistry of iron in biological media. In: Iron Metabolism-From molecular mechanisms to clinical consequences. (3rd edn) Wiley.

32. Ovesen L, Bendtsen F, Tage-Jensen U, Pedersen NT, Gram BR, et al. (1986) Intraluminal $\mathrm{pH}$ in the stomach, duodenum, and proximal jejunum in normal subjects and patients with exocrine pancreatic insufficiency. Gastroenterology 90: 958-962.

33. Das NN (2016) Periodensystem der Elemente online.

34. (2016) lonisation constants for some acids and their conjugated bases.

35. Netzer P, Brabetz-Holfliger A, Brundler R, Flogerzi B, Husler J, et al. (1998) Comparison of the effect of the antacid Rennie versus low-dose H2-receptor antagonists (ranitidine, famotidine) on intragastric acidity. Alimentary Pharmacology \& Therapeutics 12: 337-342.

36. Rohss K, Lind T, Wilder-Smith C (2004) Esomeprazole $40 \mathrm{mg}$ provides more effective intragastric acid control than lansoprazole $30 \mathrm{mg}$, omeprazole $20 \mathrm{mg}$ pantoprazole $40 \mathrm{mg}$ and rabeprazole $20 \mathrm{mg}$ in patients with gastro-oesophagea reflux symptoms. European Journal of Clinical Pharmacology 60: 531-539.

37. Stedman CA, Barclay ML (2000) Review article: comparison of the pharmacokinetics, acid suppression and efficacy of proton pump inhibitors. Aliment Pharmacol Ther 14: 963-978.

38. AstraZeneca (2010) Nexium - Esomeprazole EAHP Fragebogen zu Information von Krankenhausapothekernuber das Fertigarzneimittel, version 8

39. Documed (2011) Arzneimittelkompendium der SchweizÂ® - NexiumÂ®. In Documed, editor.

40. Johnson PE, Milne DB, Lykken GI (1992) Effects of age and sex on copper absorption, biological half-life, and status in humans. Am J Clin Nutr 56: 917 925.

41. Auterhoff H, Kovar KA, Ruf COL (1998) Identifizierung von Arzneistoffen: Stas-Otto-Gang, Dunnschichtchromatographie, Farbreaktionen, UV- und IRSpektroskopie, DC-UV-Koppelung: Wissenschaftliche Verlagsgesellschaft. 